\title{
Polyculture Strategy:
}

\section{Integration of Islamic Values, National Character, and Local Wisdom in Science Learning}

\author{
Dindin Nasrudin, Idad Suhada, Chaerul Rochman, \\ Imelda Helsy \\ Department of Science Education, Faculty of Tarbiyah and \\ Teacher Training \\ UIN Sunan Gunung Djati \\ Bandung, Indonesia \\ dindin.nasrudin@uinsgd.ac.id
}

\author{
A. Heris Hermawan \\ Department of Islamic Education Management, Faculty of \\ Tarbiyah and Teacher Training \\ UIN Sunan Gunung Djati \\ Bandung, Indonesia
}

\begin{abstract}
The approach of science learning in Islamic schools is not only directed to master the concept and its application. However, science is used as a medium to foster positive character, increase faith in the creator, relate well to others, and maintain harmony with the environment. The purpose of this research is to express a new design of science learning which is integrated with character education, Islamic values, and local wisdom. This research method is preliminary research with qualitative descriptive analysis. The results of this research: (1) identification of Islamic values, national character and local wisdom to be integrated (2) analysis of science curriculum for one subject (2) Initial design pattern of integration of Islamic values, national character and local wisdom in science learning (3) Integrated learning science strategy. This research concludes that polyculture strategy can be used as life science learning alternative, more meaningful and more humane. Need further study to apply this strategy to a broader domain.
\end{abstract}

Keywords - character education; islamic values; local wisdom; polyculture strategy

\section{INTRODUCTION}

Islamic education began to be well-known in the world, including in Europe and America, even the word Madrasah, another name for school became common in Westerners' vocabulary [1]. Islamic education in Indonesia has a long history because Islam has been the religion of most of the people of the archipelago since the thirteenth century [2]. In Indonesia itself, Islamic education refers to learning in Islamic schools (madrasah), Islamic religious learning in public schools and non formal learning in pesantren [3]. Learning in Islamic schools with public schools has several differences, one of which is the number of subjects and approaches of learning.

In the Indonesian context, there should be a different approach to learning science in Islamic schools with public schools. Science in Islamic schools should be designed to reunite the concept of science from the same God [4]. In Islamic schools, science is studied in order to increase confidence in God and "supposed" science in accordance with the sacred text that is believed. Integration of Science-Religion became an answer as expressed by earlier Islamic thinkers such as Nasr [5] and Bakr [6].
Islamic education is not only intended to convey the contents of the Islamic Education curriculum, but actually to build good student character [7]. However, there is still an imbalance between goals and reality. Even today, there is moral degradation among students, including in Islamic institutions. To overcome this, the president even issued a presidential regulation through a program to strengthen character education [8]. Strengthening character education is a joint task, not charged to the teacher of Religion alone but rather becomes the duty of all subject teachers, including science [9]. Science learning in madrasas must be built and aimed at developing students' character education

Learning science in Islamic schools is not only directed to master the concept and its application but also directed at the formation of good character of students, become religious beings (subject to the concept of God), and fulfill their duties as world leaders [10], love and care for each other environment which in turn will form civilized communal society [11]. Therefore, science learning must be designed and enriched with religious, character and contextual values with local cultural wisdom as a source of character education. This paper will outline the model of integration of science with Islamic values, character education and local wisdom as well as what kind of science learning strategies are considered suitable.

\section{METHOD}

This research is a preliminary study using qualitative descriptive analysis. In accordance with the research objectives, to get an integrated science learning strategy, the research conducted by researchers follows the steps; (1) identification of values, (2) reviewing and analyzing science curricula, (3) finding integration models and (4) developing learning designs.

In the value identification stage, researchers use literature studies to find out what values are to be integrated in science learning. The taking of Islamic values is taken from the principles of Islamic teachings namely aqidah, sharia and akhlaq [12]. The national character values are taken from the five priority characters of the Ministry of Education and Culture covering integrity, mutual cooperation, nationalist and 
religious independence [13]. Meanwhile, the value of local wisdom taken from the local wisdom of the people of West Java consists of picking up the grind, picking out the compassion, picking up foster care and repeating the wawangi (silih asah, silih asih, silih asuh dan silih wawangi )[14, 15].

At the stage of analyzing the science curriculum, the curriculum used was the revised 2016 curriculum of 2013 [16]. The main material that will be used as an example is the Substance and Characteristics. Basic competencies to be chosen are 3.3 for cognitive aspects and 4.3 for psychomotor aspects, namely understanding the concepts of mixtures and single substances (elements and compounds), physical and chemical properties, changes in physics and chemistry in everyday life and presenting the results of investigations or work on properties solution, physical change and chemical change, or separation of mixture.

The integration model used in this study adopted a previous study, namely the adaptation integration model [17]. With the adaptation integration model, science learning will be integrated through the selection of appropriate learning contexts. After determining the integration model, the final step is the preparation of the instructional design. Strategies for developing learning designs and implementing learning are using polyculture strategies. The term polyculture is derived from the term agriculture, which is a model of intercropping, that is, planting various kinds of plants in the same place [18]. The goal is to get multiple benefits without disturbing the main crops.

Policulture strategy in this research is interpreted as an effort to teach science to the learners as the main goal by including strengthening of Islamic values, national character and local wisdom of West Java community at the same time.

\section{RESULTS AND DISCUSSION}

\section{A. Identification of Values}

The first phase of this research is to find the main values of the main points of Islam, national character and local wisdom that will be integrated in science learning. Table 1 shows the results of identifying values for all components.

In the practice of learning, not all of these values can be integrated in science learning. Only values that correspond to the context of learning will be taken. The more values contained in learning, the better the learning will be. That is, students will get a lot of things from what they learn.

The main thing that must be considered by the teacher is not to force the merging of values that do not match. Don't be impressed by imposing "other values" on science learning. The teacher must remember that this is science learning.
TABLE I. IDENTIFICATION OF ISLAMIC VALUES, NATIONAL CHARACTER, AND LOCAL WISDOM

\begin{tabular}{|c|c|c|}
\hline Comp. & Values & Illustration \\
\hline \multirow[b]{3}{*}{ 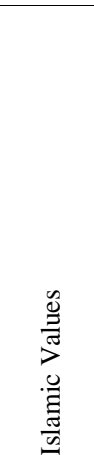 } & $\begin{array}{l}\text { Aqidah } \\
\text { (arkan al- } \\
\text { iman) }\end{array}$ & $\begin{array}{l}\text { Belief in Allah, The Only God, the } \\
\text { Angels, Holy Books, the Prophets, the } \\
\text { Day of Judgement and God's } \\
\text { predestination }\end{array}$ \\
\hline & $\begin{array}{l}\text { Syariah } \\
\text { (arkan } \\
\text { islam) }\end{array}$ & $\begin{array}{l}\text { Shahada (declaration of faith), salah } \\
\text { (obligatory prayer), zakat (compulsory } \\
\text { giving), sawn (fasting in the moth of } \\
\text { Ramadhan), hajj (filgrimage to Mecca) }\end{array}$ \\
\hline & $\begin{array}{l}\text { Akhlaq } \\
\text { (ihsan) }\end{array}$ & $\begin{array}{l}\text { an Arabic term meaning "perfection" } \\
\text { or "excellence". It is a matter of taking } \\
\text { one's inner faith and showing it in both } \\
\text { deed and action, a sense of social } \\
\text { responsibility borne from religious } \\
\text { convictions. }\end{array}$ \\
\hline \multirow{5}{*}{ 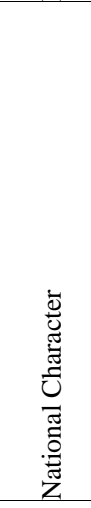 } & integrity & $\begin{array}{l}\text { the qualifications of being honest and } \\
\text { having strong moral principles; moral } \\
\text { uprightness. It is generally a personal } \\
\text { choice to hold oneself to consistent } \\
\text { moral and ethical standards. }\end{array}$ \\
\hline & cooperation & $\begin{array}{l}\text { the process of groups of organisms } \\
\text { working or acting together for } \\
\text { common or mutual benefit, as opposed } \\
\text { to working in competition for selfish } \\
\text { benefit }\end{array}$ \\
\hline & independent & $\begin{array}{l}\text { not dependent; not contingent or } \\
\text { depending on something else; free }\end{array}$ \\
\hline & nationalist & An advocate of nationalism. \\
\hline & religious & Committed to the practice of religion \\
\hline \multirow{4}{*}{ 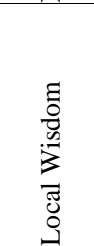 } & silih asah & $\begin{array}{l}\text { sharpen each other's mind; remind } \\
\text { each other }\end{array}$ \\
\hline & silih asih & love each other \\
\hline & silih asuh & caring for each other; guide each other \\
\hline & silih wawangi & $\begin{array}{l}\text { connect each other positive things to } \\
\text { give a positive }\end{array}$ \\
\hline
\end{tabular}

\section{B. Science Curriculum Analysis}

After all values have been identified, the next step is to determine the topic of science that will be discussed. The main activity in this process is to analyze the science curriculum first, especially Core Competencies, and Basic Competencies.

TABLE II. BASIC COMPETENCE, LEARNING MATERIAL AND ACTIVITY

\begin{tabular}{|c|c|}
\hline Part of Syllabus & Content \\
\hline Basic Competence & $\begin{array}{l}\text { Understand the concepts of mixtures and } \\
\text { single substances (elements and } \\
\text { compounds), physical and chemical } \\
\text { properties, changes in physics and } \\
\text { chemistry in everyday life }\end{array}$ \\
\hline Learning Material & $\begin{array}{l}\text { Substances and Characteristics } \\
\text { - Solid, Liquid, and Gas } \\
\text { - Elements, Compounds, and Mixes } \\
\text { - Physical and chemical properties } \\
\text { - Physical and chemical changes }\end{array}$ \\
\hline Learning Activity & $\begin{array}{l}\text { - Observing various objects in } \\
\text { everyday life that are undergoing } \\
\text { change, for example water becomes } \\
\text { ice, ice becomes water, water } \\
\text { becomes steam, paper is burned } \\
\text { into ash, iron rusts, food becomes } \\
\text { stale, etc. } \\
\text { - Conduct investigations on the }\end{array}$ \\
\hline
\end{tabular}




\begin{tabular}{|l|l|}
\hline & $\begin{array}{l}\text { characteristics of substances (solid, } \\
\text { liquid, and gas) and collect }\end{array}$ \\
information about elements, \\
compounds, and mixtures \\
- Investigate acids, bases, and salts \\
using artificial and natural \\
indicators \\
Conducting mixed separation \\
technique experiments, for example \\
through distillation, \\
chromatography, or sublimation \\
Presents the results of \\
investigations of physical and \\
chemical properties in everyday life \\
and discusses them with friends
\end{tabular}

\section{Integration Model}

In discipline, Islamic values, character education and local wisdom are born from different disciplines although there are also slices. Indeed, different disciplines must be presented in different subjects. However, because of the needs and demands, the different disciplines must be presented in the same event. Therefore, combining some of these disciplines is a necessity. This paper will not discuss how this philosophical foundation of integration is derived. However, this paper will focus on a model of integration that can be practically practiced in the field.

There are various models and interpretations in explaining the word "integration" as in integrated education. One possible meaning of "integrated" is the integration of science and nonscience subjects [19]. The integration model that can be done to combine Islamic values, character education and local wisdom in science learning is shown in Figure 1.

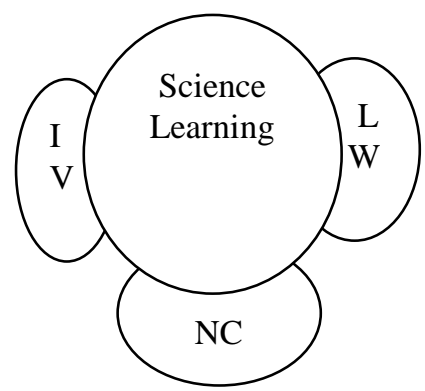

Fig. 1. Integration model.

\section{Integrated Science Learning Design}

The final result of this study is an integrated science learning design product. Table 3 below will show examples of learning Substances and Characteristics that are combined with Islamic values, national character and local wisdom.
TABLE III. DESIGN OF LEARNING MATERIALS OF THE ART AND CHARACTERISTICS IS INTEGRATED VALUE OF ISLAM, CHARACTER AND LOCAL WISDOM

\begin{tabular}{|c|c|}
\hline Steps & Actitivities \\
\hline Introduction & $\begin{array}{l}\text { - The teacher reveals the learning objectives (as } \\
\text { per the curriculum) } \\
\text { - Teacher shows a video / simulation } \\
\text { - demonstration of three types of objects (solid, } \\
\text { liquid, and gas) and students observe them } \\
\text { - Teachers facilitate learners to provide } \\
\text { questions related to the phenomenon that } \\
\text { occurs } \\
\text { - The teacher directs the student to the lesson }\end{array}$ \\
\hline $\begin{array}{l}\text { Core } \\
\text { Activity }\end{array}$ & $\begin{array}{l}\text { - The teacher invites students to try simulations } \\
\text { / demonstrations exemplified by the teacher } \\
\text { - The teacher asks students to identify the } \\
\text { properties of objects } \\
\text { - By using the analogy method, students are } \\
\text { asked to associate the properties of objects } \\
\text { with respect to human character (for example: } \\
\text { the bond between the atoms of solids is the } \\
\text { same as the integrity of human beings) } \\
\text { - The teacher provides examples of the nature of } \\
\text { things with Islamic values, character and local } \\
\text { wisdom } \\
\text { - The teacher asks students to collect, analyze, } \\
\text { and present their findings regarding the } \\
\text { concept of substances and their characteristics } \\
\text { and then relate them to those values } \\
\text { - The teacher asks representatives of students to } \\
\text { present the results of their work in front of the } \\
\text { class, other students are asked to add, } \\
\text { comment on or refute }\end{array}$ \\
\hline Closing & $\begin{array}{l}\text { - The teacher concludes the concepts of } \\
\text { substances and characteristics briefly } \\
\text { - Teachers provide "new meaning" to the theory } \\
\text { of substances that have been studied with } \\
\text { Islamic values, character education and local } \\
\text { wisdom } \\
\text { - Teacher asks students to reflect on the learning } \\
\text { that has been done }\end{array}$ \\
\hline
\end{tabular}

\section{CONCLUSION}

Science teachers are fully responsible for all learning processes. He is the one who determines where to take the direction of learning. Science teachers are currently required to facilitate more meaningful science learning. Science is not only directed to master the concept and apply it. The ultimate goal of science is so that humans are aware of their God, respect each other and appreciate their cultural heritage.

For science to be more meaningful and double-impact, it cannot be learned by itself. It must be integrated with other disciplines. Appropriate integration model and appropriate learning strategy are required. Polyculture strategy can be used as an alternative to solve that. With such strategy, science lessons according to the curriculum are not diminished in the least and the outcome of integration is expected to have an impact on the output and outcome of science learning, which is a useful human being.

\section{ACKNOWLEDGMENT}

The researcher would like to thank the Tarbiyah and Teaching Faculty who facilitated us in presenting the results of this study. 


\section{REFERENCES}

[1] P. Karlsson, and A. Mansory, Islamic Education in Afghanistan. Handbook of Islamic Education, 2017, pp. 1-3.

[2] D. Rosyada, Islamic Education in Indonesia. In Flinders University Seminar on Rumah Budaya, April 2014.

[3] H. Haidar Putra Daulay MA, Pendidikan Islam dalam sistem pendidikan nasional di Indonesia. Kencana, Juli 2014.

[4] A. Azra "Islamic Education And Reintegration Of Sciences: Improving Islamic Higher Education," Media Syari'ah, vol. 15, no. (2), pp. 257264, 2017.

[5] S.H. Nasr, Islam dan Nestapa Manusia Modern (Terjemahan). 1983.

[6] O. Bakar, History and Phylosophy of Islamic Science. 1999.

[7] N. Omar, and Noh MA, "Islamic Education Teaching Practice Based on the Cultural Diversity of Students," Academic Journal of Interdisciplinary Studies, vol. 4, no. (1 S1) pp. 135, 2015.

[8] E. Mulyasa, "Revolusi Mental Dalam Pendidikan Untuk Merevitalisasi Nilai-Nilai Pancasila Dan Menumbuhkembangkan Wawasan Kebangsaan". In Prosiding Seminar Nasional Program Pascasarjana 2017 Dec 7.

[9] M.W. Berkowitz, and C.B. Me'inda, "Character education. The Role of Moral Reasoning on Socioscientific Issues and Discourse in Science Education,"vol. 19, p.117, 2003.

[10] M.A. Ramdhani, and H. Muhammadiyah "The Criteria of Learning Media Selection for Character Education in Higher Education," pp. 174$182,2015$.

[11] H. Koizumi, "Scientific learning and education for human security and well-being". In Children and Sustainable Development Springer International Publishing. pp. 239-257, 2017.
[12] E. Syaripudin, I. Safrudin and A.A. Siddiq, "Application of Islamic Values Employees Working in Disciplinary Enforcement Efforts (Case Study in PT. Ina Cookies Bojong Koneng Bandung” 2017.

[13] I. Anshori, "Penguatan Pendidikan Karakter di Madrasah," Halaqa: Islamic Education Journal, vol. 1, no. (2) pp. 63-74, 2017.

[14] R. Rokayah, D. Disman and S.A. Sapriya, "Preliminary Development of Sundanese Local Wisdom Questionnaire (SLWQ) Through Educational College Students' Responses," Advanced Science Letters, vol. 23, no. (11), pp. 10922-4, 2017.

[15] D. Koswara, D. Haerudin, and R. Permana, "Nilai-nilai Pendidikan Karakter Bangsa Dalam Khazanah Sastra Sunda Klasik: Transformasi Dari Kelisanan (Orality) Ke Keberaksaraan (Literacy) Carita Pantun Mundinglaya Di Kusumah (Kajian Struktural-semiotik Dan Etnopedagogi)," Jurnal Penelitian Pendidikan, vol. 14, no. (2), 2016.

[16] I Kurniasih and S Berlin, Revisi Kurikulum 2013 Implementasi Konsep dan Penerapan. Kata Pena. 2016.

[17] C. Rochman, D. Nasrudin, Rokayah, N. Hermita, A. Malik and I. Suhada, "Integration of Local Wisdom in Science Learning" presented in Asian Education Sympoium Lombok, Indonesia, 2017.

[18] W. Weiseman, D. Halsey, and B. Ruddock, Integrated Forest Gardening. The Complete Guide to Polycultures and Plant Guilds in Permaculture System. Chelsea Green, Vermont, 2014.

[19] M.A. Lubis, and I.S. Wekke, :Integrated Islamic education in Brunei Darussalam: the hopes and challenges," EDUCARE, vol. 1, no. (2), 2016. 